九州大学学術情報リポジトリ

Kyushu University Institutional Repository

\title{
Surface Erosion Control by Contour-Felled Log Erosion Barriers in Post Fire Areas in Eastern Coastal Regions of the Republic of Korea
}

Ahn, Young-Sang

Department of Housing environmental design, College of Division of Forest Resources, College of Agriculture and Life Sciences, Chonnam National University

Otsuki, Kyoichi

Kasuya Research Forest, Kyushu University

Ryu, Soung-Ryoul

Department of Renewable Resources, Faculty of Agricultural, Life \& Environmental Sciences, University of Alberta

Chun, Kun-Woo

Department of Forest Resources, College of Forest and Environmental Sciences, Kangwon National University

他

https://doi.org/10.5109/27371

出版情報：九州大学大学院農学研究院紀要. 58 (2)，pp.389-394，2013-09. Faculty of Agriculture， Kyushu University

バージョン:

権利関係: 


\title{
Surface Erosion Control by Contour-Felled Log Erosion Barriers in Post Fire Areas in Eastern Coastal Regions of the Republic of Korea
}

\author{
Young-Sang AHN ${ }^{1}$, Kyoichi OTSUKI ${ }^{2}$, Soung-Ryoul RYU ${ }^{3}$, Kun-Woo CHUN ${ }^{4}$, \\ Ki-Wan AN ${ }^{1}$, Kye-Han LEE ${ }^{1}$, Hyung-Tae CHOI ${ }^{5}$, \\ Shigeru MIZUGAKI ${ }^{6}$ and Jung-II SEO ${ }^{4,7, *}$
}

Laboratory of Ecohydrology, Division of Forest Sciences, Department of Agro-Environmental Sciences, Faculty of Agriculture, Kyushu University, Sasaguri, Fukuoka 811-2415, Japan

(Received April 25, 2013 and accepted May 9, 2013)

\begin{abstract}
Recently, large forest fires have occurred along the Baekdu mountain range in the eastern coastal regions of the Republic of Korea. The turbidity of water in streams increased substantially after the forest fires, leading to substantial deterioration in the water quality. Residents living near the burned areas have requested remediation measures to reduce the turbidity in streams during rainfall events. Our research was conducted at the locations affected by the Donghaean fire in 2000 to investigate: 1) the influence of forest fires on the physical properties of the soil and 2) the effectiveness of contour-felled log erosion barriers (CFLEBs) in reducing surface soil erosion. The CFLEBs is a remediation technique in which felled burnt trees are laid along the ground contour to promote water infiltration into the soil and to reduce the movement of sediment by decreasing the amount of surface runoff. The results showed that the bulk density of the surface soils in the burned areas was greater than that in the unburned areas, and that the mesopore ratio of the surface soils in the burned areas was less than that in the unburned areas. These results implied that forest fires damaged the physical structure of the surface soil and made the surface soil more vulnerable to post-fire runoff and hillslope erosion. The slope lysimeter experiments conducted over two years from May 2010 to June 2012 showed that the annual average sediment yields were $17.8 \mathrm{~g} \mathrm{~m}^{-2} \mathrm{yr}^{-1}$ in areas treated with CFLEBs and $133.6 \mathrm{~g} \mathrm{~m}^{-2} \mathrm{yr}^{-1}$ in areas not treated with CFLEBs. These results demonstrate that CFLEBs are an effective measure for controlling surface soil erosion and thus reducing turbidity in streams. Since burnt trees are often cut down in the Republic of Korea after forest fires to prevent the spread of damage caused by insects epidemics, the construction of CFLEBs from already felled trees would be an economically and ecologically useful method to reduce surface soil erosion and turbidity in streams over large scales.
\end{abstract}

Key words: erosion control, forest fire, Korea, log barrier, soil property

\section{INTRODUCTION}

Forest fires were mainly viewed as destructive events with no beneficial consequences prior to the 1980s (Spurr and Barnes, 1980). However, further studies on the ecological roles of fire revealed that forest fire is a critical

${ }^{1}$ Department of Housing environmental design, College of Division of Forest Resources, College of Agriculture and Life Sciences, Chonnam National University, Gwangju 500-757, Republic of Korea

${ }^{2}$ Kasuya Research Forest, Kyushu University, Sasaguri, Fukuoka 811-2415, Japan

Department of Renewable Resources, Faculty of Agricultural, Life \& Environmental Sciences, University of Alberta, Edmonton T6G 5H5, Canada

${ }^{4}$ Department of Forest Resources, College of Forest and Environmental Sciences, Kangwon National University, Chuncheon, Gangwon 200-701, Republic of Korea

${ }^{5}$ Division of Forest Water and Soil Conservation, Department of Forest Conservation, Korea Forest Research Institute, Seoul 130-712, Republic of Korea

${ }^{6}$ Water Environment Engineering Research Team, Civil Engineering Research Institute for Cold Region, Sapporo, Hokkaido 062-8602, Japan

Department of Forest Resources, College of Industrial Sciences, Kongju National University, 54 Deahakro, Yesaneup, Yesangun, Chungcheongnamdo 340-702, Republic of Korea

* Corresponding author (E-mail: jiseo.watershed@gmail.com) process that maintains the integrity of many forest ecosystems and often has beneficial effects on forest productivity (Kutiel and Naveh, 1987; Brose et al., 1999). It is also recognized that the burning of litter and soil organic matter can increase the water repellency of the surface soil layer, reduce water infiltration rates, and increase surface runoff, resulting in high amounts of soil erosion (DeBano, 2000; DeBano et al., 2005). In general, forest fires and the associated heat to the ground surface affect the porosity of the surface soil (DeBano et al., 2005). The condition of the soil surface after a fire is an important factor that determines the direction of water movement and the extent of surface soil erosion (Yao, 2003).

Surface soil erosion is a landscape level process, and its scale varies by local geology, topography, vegetation, and climate (Dedkov and Mozzherin, 1996; Hicks et al., 1996; Ahn et al., 2006, 2010). The rate of surface soil erosion tends to increase on steeper slopes, and it accelerates after the forest floor is burnt by the fire (Larsen and MacDonald, 2010; Polyakov et al., 2010). Sediments originating from eroded soils typically consist of silt and colloids, and these particles can be especially detrimental to water quality with respect to human, agricultural, and industrial uses of the water and to organisms that live in aquatic environments (Lemly, 1982; Bruton, 1985; Ahn 
et al., 2006, 2008, 2010).

In the Republic of Korea, the most recent massive forest fires (e.g., the Goseong fire in 1996 (3,762 ha), the Donghaean fire in 2000 (23,794 ha), and the Yangyang fire in 2005 (973 ha)) occurred in the eastern coastal region (Fig. 1). It is thought that these large-scale forest fires have been caused by the strong and dry winds blowing in spring and the widespread of Pinus densiflora forests prone to crown fires (Lim, 2000; Lim et al., 2010; Ahn et al., in press). These forest fires have resulted in large amounts of soil erosion, especially during the summer rainy season. The residents in the vicinity of the burned forest areas have requested remediation measures to reduce turbidity levels in streams (Ahn et al., in press). Since the forests in the region are on steep slopes, they are highly vulnerable to sedimentrelated disasters caused by torrential rainfall in summer. In fact, the typhoons Rusa (2002) and Maemi (2003) caused numerous landslides and substantial damage to the region, especially in the areas that were burned by the Donghaean fire in 2000 (Fig. 2).

In the Republic of Korea, check dams are often constructed in stream channels in burned forested areas to control sediment transport associated with heavy rainfall

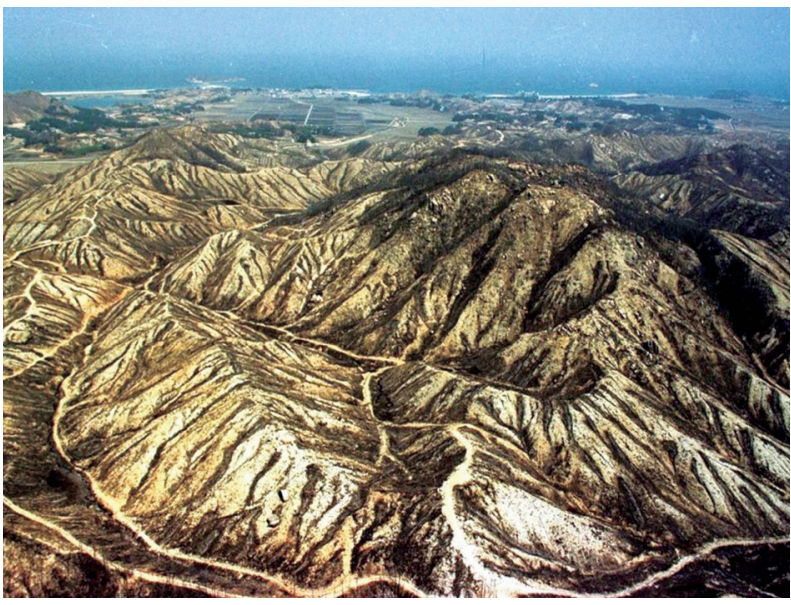

Fig. 1. Forest burned by the large-scale Donghaean fire in 2000. Image from Chun (2003).

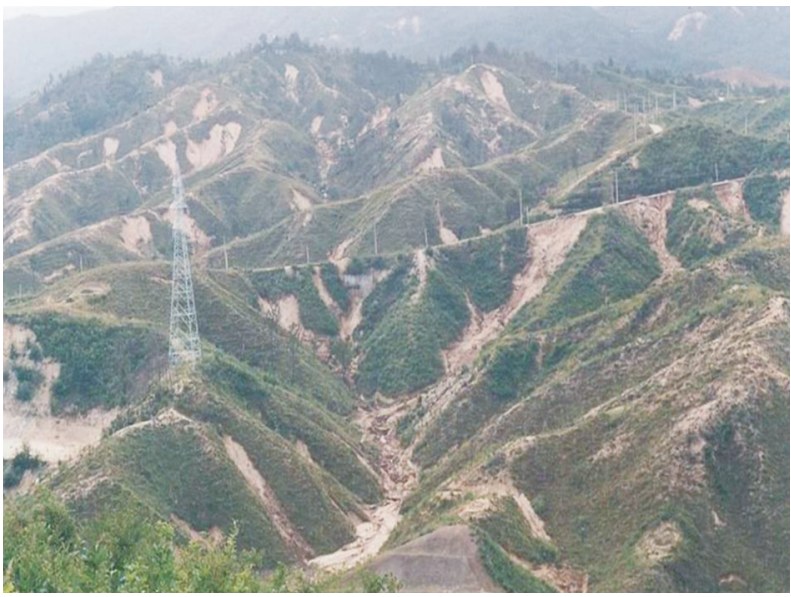

Fig. 2. Landslides in the burned forest caused by Typhoon Rusa in 2002 .
(Lim et al., 2010). However, the check dams can adversely affect aquatic organisms by preventing their in-stream movement. In addition, these erosion control projects are difficult and expensive to implement over large areas of burned forest (Ahn et al., in press). Therefore, many natural resource managers are currently seeking eco-friendly and efficient restoration measures to control surface soil erosion over broad areas in burned forest regions. Contour-felled log erosion barriers (CFLEBs) made of fire killed trees could be an effective measure for controlling surface soil erosion and reducing turbidity in streams. Burnt trees are often cut down after forest fires in the Republic of Korea to prevent damage caused by insect epidemics, and considered as waste material. Therefore, the construction of CFLEBs using felled burnt trees could be an economically and ecologically useful method to reduce surface soil erosion and turbidity in streams over larger scales (Lim et al. 2010; Ahn et al., in press).

The objectives of this study were 1) to examine the influence of forest fires on the physical properties of the soil and 2) to assess the effects of CFLEBs to reduce surface soil erosion. First, we investigated differences in bulk density and mesopore ratio in the surface soil from the burned and unburned areas. Second, we quantified the effects of CFLEBs on sediment yields in the burned areas. We anticipate that the results of this study explain how CFLEBs are helpful in preventing soil erosion, and consequently, that they can be used to decrease water turbidity in areas burned during massive forest fires.

\section{MATERIALS AND METHODS}

\section{Study Site}

Our study was conducted on a mountain hillslope in Samcheok city in the eastern coastal region of the Gangwon province, Republic of Korea (Fig. 3). Located on the eastern slope of the Baekdu mountain range which mostly lies at an elevation higher than 1,000 m above sea level, this region has a maritime climate. The winds are strong and dry due to the Föhn winds that blow over the mountain range (Lim, 2000; Lim et al., 2010). The aver-

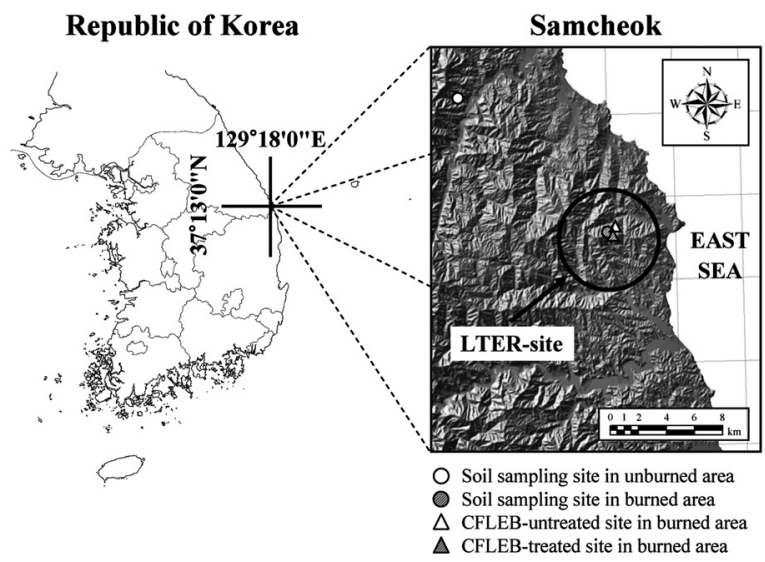

Fig. 3. Location of the study site. 


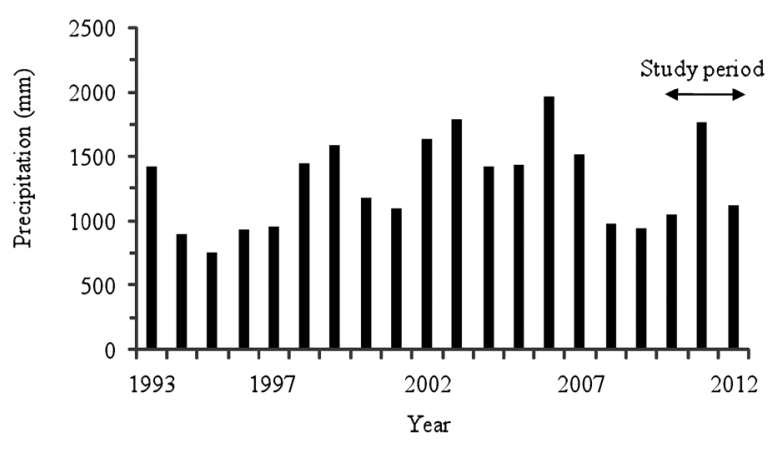

Fig. 4. Annual precipitation at the study site.

age annual precipitation during our study period was $1,418 \mathrm{~mm}$ (Fig. 4). Approximately half of the annual precipitation fell during the summer months (e.g. $525-648 \mathrm{~mm}$ ), whereas winter precipitation comprised a smaller percentage of the annual total precipitation (e.g. $157-216 \mathrm{~mm}$ ). During the spring season, the eastern coastal region has very dry weather and is particularly susceptible to fires. The amount of annual precipitation during our erosion study period was close to the average amount during the last 20 years (Korea Meteorological Administration, 2012).

The region was once widely covered by the forests consisting of $P$. densiflora and Quercus spp. The Donghaean fire occurred in April 2000 burned 23,794 ha of the region and severely damaged the forests composed of pine trees (Fig. 1). The Korea Forest Research Institute (KFRI) has designated a section in Samcheok city burned by the fire as the Long-Term Ecological Research (LTER) site to study the influence of fires on forest ecosystems and to develop effective restoration methods in the burned area (Shin and Lee, 2004). Our study sites were set in the LTER site.

The damaged trees in the burned areas of the study site have been cut down and $P$. densiflora seedlings have been replanted since 2006 to recover the production of pine mushroom (Tricholoma matsutake). Recently, the portions of the burned areas are covered with regenerated roots and sprouts from fire-damaged oaks below $1 \mathrm{~m}$ in height (Hwang et al., 2011). The soil parent materials in these areas are primarily granite and limestone. The surface layer in the study area was composed mostly of inorganic material due to the combustion of vegetation and the litter layer during the forest fires. The presence of such soils can heighten the risk for significant erosion and landslides (Fig. 2).

\section{Field Survey and Laboratory Analyses}

To examine the influence of forest fires on the bulk density and mesopore ratio of soil, surface soil samples were collected during 2002-2005 from the burned and unburned areas near the erosion study sites (Fig. 3). The soil samples were collected at depths of $0-5 \mathrm{~cm}$ using a soil sampler (DIK-115B) equipped with $100 \mathrm{~cm}^{3}$ stainless steel cylinders. Bulk densities of the surface soils were calculated after drying the samples for $24 \mathrm{~h}$ at $105^{\circ} \mathrm{C}$. The mesopore ratios were measured under low-
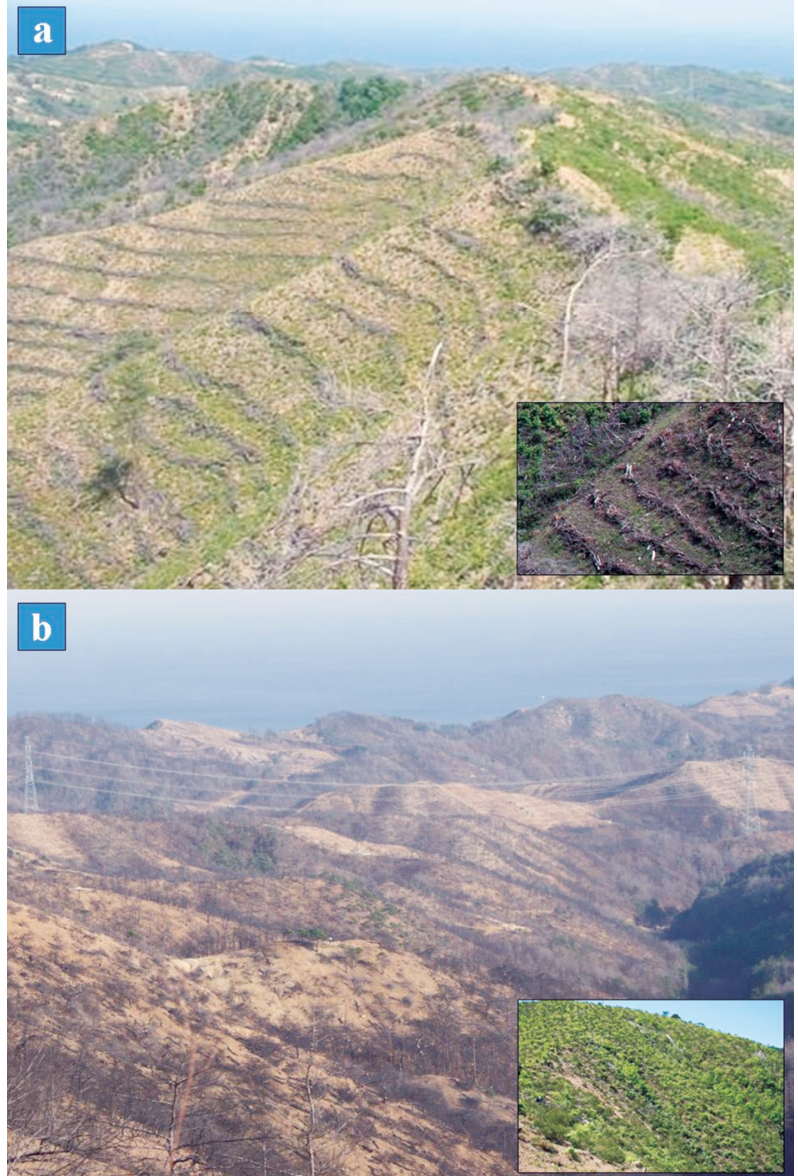

Fig. 5. Sites (a) treated with contour-felled log erosion barriers (CFLEB) and (b) untreated.

pressure conditions at a $\mathrm{pF}$ of 2.7 with an automatic pressure controller (DIK-9211, Daiki Rika Kogyo Co., Ltd.) after capillary saturation of the surface soil within a $100 \mathrm{~cm}^{3}$ stainless steel cylinder (Jeong et al., 2001).

The erosion study sites were set in close proximity to each other in the same catchment of the LTER site (Fig. 3). The erosion study sites were categorized by CFLEBs treatment: (i) treated plots and (ii) untreated plots (Fig. 5). Three lysimeters, $3 \mathrm{~m}$ wide and $5 \mathrm{~m}$ long, were installed for each treatment to evaluate reductions in surface soil erosion by the application of CFLEBs. At the CFLEB treatment lysimeters, felled burnt trees of approximately uniform density $\left(0.34 \mathrm{~m}^{3}\right.$ per lysimeter $)$ were arranged along the ground contour to provide a mechanical barrier to overland water flow and soil erosion. The average slope angles of the lysimeters at the treated and untreated plots were $38^{\circ}$ (range of $36^{\circ}-39^{\circ}$ ) and $40^{\circ}$ (range of $35^{\circ}-43^{\circ}$ ), respectively. At the base of each lysimeter, a catchment barrel was installed to trap sediments eroded from the lysimeter (Fig. 6). The sediment yield was annually measured over two years from May 2010 to June 2012. The sediment yields were measured twice in the first year from May 2010 to June 2011 and once in the second year from May 2011 to June 2012. All collected sediments were sieved to separate leaf and wood particles from the sediment. The filtered samples were oven-dried at $110^{\circ} \mathrm{C}$ for $24 \mathrm{~h}$ and then weighed to obtain the sediment yield. 

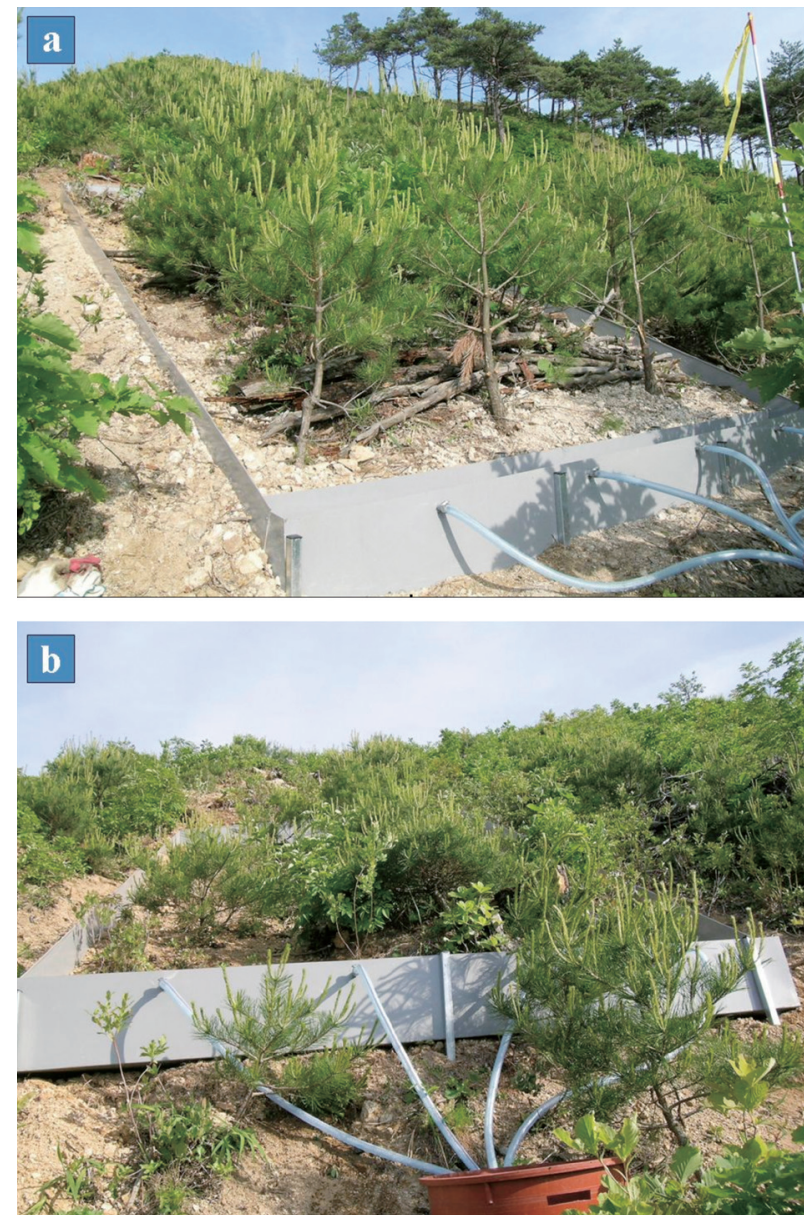

Fig. 6. Experimental lysimeters (a) treated with contour-felled log erosion barriers (CFLEB) and (b) untreated.

\section{Statistical Analyses}

A Mann-Whitney U test was used to evaluate the effect of fire on the bulk density and mesopore ratio of the surface soils. A Mann-Whitney U test was also used to assess the effects of CFLEB treatments on sediment yields within the burned area. The sediment yield data were log-transformed to stabilize the variances. All statistical analyses were conducted with SPSS software (version 20).
Table 1. Bulk density and mesopore ratio of the surface soils in the unburned and burned areas ${ }^{\mathrm{a}, \mathrm{b}}$

\begin{tabular}{ccc}
\hline & $\begin{array}{c}\text { Bulk density } \\
\left(\mathrm{g} \mathrm{cm}^{-3}\right)\end{array}$ & $\begin{array}{c}\text { Mesopore ratio } \\
(\%)\end{array}$ \\
\hline Unburned area $(n=4)$ & $0.92 \pm 0.02$ & $41.0 \pm 0.52$ \\
& $(0.89-0.94)$ & $(40.3-41.5)$ \\
Burned area $(n=4)$ & $1.11 \pm 0.05$ & $34.6 \pm 2.34$ \\
& $(1.05-1.17)$ & $(32.4-37.6)$
\end{tabular}

a The bulk density and porosity are expressed as the mean \pm standard deviation.

${ }^{\mathrm{b}}$ The values in parentheses indicate the range of bulk density and mesopore ratio values.

\section{RESULTS}

\section{Changes in Soil Properties Caused by the Forest Fires}

To evaluate the influence of forest fires on the physical properties of the soil, the bulk density and mesopore ratio of surface soils from the burned and unburned areas were analyzed (Table 1). The bulk densities of the surface soil were 1.11 and $0.92 \mathrm{~g} \mathrm{~cm}^{-3}$ in the burned and unburned areas, respectively. The bulk density of the surface soil in the burned areas was significantly higher than that in the unburned areas $(p<0.05)$.

The mesopore ratio of the surface soil was significantly higher in the unburned areas $(41.0 \% \pm 0.52 \%)$ than in the burned areas $(34.6 \% \pm 2.34 \%)(p<0.05)$. The mesopore ratio in the surface layer of the soil was negatively correlated with the bulk density (Table 1).

\section{Reduction in Surface Soil Erosion by CFLEBs}

Sediment yields were highly variable and showed no apparent relationships with precipitation amounts (Table 2 ). The average sediment yields from the CFLEB lysimeters and the untreated lysimeters were 17.8 and $133.6 \mathrm{~g}$ $\mathrm{m}^{-2}$, respectively (Table 2 ). The sediment yields from the CFLEB lysimeters were significantly lower than those from the untreated lysimeters $(p<0.05)$. These results indicate that CFLEBs arranged at a density of roughly $0.34 \mathrm{~m}^{3}$ per lysimeter were responsible for an approximately 8 -fold reduction in the sediment yield from the

Table 2. Sediment yields at the untreated and treated lysimeters during the past two years ${ }^{\mathrm{a}, \mathrm{b}}$

\begin{tabular}{cccc}
\hline \multirow{2}{*}{ Observation period } & $\begin{array}{c}\text { Precipitation } \\
(\mathrm{mm})\end{array}$ & Untreated $(n=3)$ & Sediment yield $\left(\mathrm{g} \mathrm{m}^{-2} \mathrm{yr}^{-1}\right)$ \\
\cline { 3 - 4 } May 2010-June 2011 & 1,518 & $142.6 \pm 129.6(37.9-287.5)$ & $17.2 \pm 11.7(4.2-26.8)$ \\
May 2010-September 2010 & 651 & $75.2 \pm 69.0(16.8-151.3)$ & $4.9 \pm 5.4(1.6-11.2)$ \\
October 2010-June 2011 & 867 & $67.4 \pm 60.8(21.1-136.2)$ & $12.2 \pm 8.5(2.6-18.4)$ \\
July 2011-June 2012 & 1,318 & $124.6 \pm 116.6(33.3-255.9)$ & $18.5 \pm 12.3(4.9-28.8)$ \\
Average & 1,418 & $133.6 \pm 110.7(33.3-287.5)$ & $17.8 \pm 10.8(4.2-28.8)$ \\
\hline
\end{tabular}

\footnotetext{
${ }^{\text {a }}$ The sediment yield is expressed as the mean \pm standard deviation.

${ }^{\mathrm{b}}$ The values in the parentheses indicate the range of the sediment yield values.
} 
burned slopes. These resulted sediment yields could represent the typical patterns of sediment yields since these measurement were taken under average precipitation condition (Fig. 4).

\section{DISCUSSION}

Soil organic matter creates and stabilizes soil aggregates; thus, organic matter can contribute to the generation of porous, well-structured soil. Forest fires reduce soil organic matter and decrease soil porosity, which can lower water infiltration rates and increase surface runoff resulting in exacerbated soil erosion (DeBano, 2000; Yao, 2003; Ahn et al., in press). Especially, mesopores play a major role in infiltration rates in the surface soils because these pores are mostly dominated in soils (Shin et al., 2007).

The increases in bulk density and decreases in the mesopore ratio of the surface soils in the burned area implied that previous forest fires in the region destroyed most of the surface soil structure. The destruction of the soil structure has likely made the soil more vulnerable to post-fire runoff and surface soil erosion on the burned hillslopes (DeBano, 2000; Yao, 2003). In addition to the influence of forest fires, the steep slopes and decomposing granite in the area likely contributed to the acceleration of surface soil erosion (Fig. 2). The burned areas in the eastern coastal region of the Republic of Korea have been recovered by some vegetation cover via $P$. densiflora planting efforts and the natural regeneration of roots and sprouts from fire-damaged oaks (Choung et al., 2004; Lim et al., 2010). However, the physical structures of the surface soils in the burned area were not fully recovered (Table 1). Thus, there is still the potential for severe soil erosion and high water turbidity during rainfall events (Ahn et al., in press).

In the Republic of Korea, forest fire management activities, including the construction of firebreaks and check dams and the use of other post-fire rehabilitation measures, have been implemented to decrease the potential for post-fire erosion events due to intense rainfall (Lim et al., 2010). Unfortunately, these emergency rehabilitation activities are difficult to implement over large spatial scales because of the substantial costs associated with such projects. Previous studies have shown that cost-effective CFLEB treatments can reduce water velocity, break up concentrated flows, create hydraulic roughness, and prevent sediment erosion in burned watersheds (Robichaud et al., 2005; Lim et al., 2010). This study showed that the CFLEBs in burned areas can significantly reduce sediment yields. The trapped sediments were concentrated in the upper sections of the treated sites, where burned trees were stacked on top of each other. This suggests that the stacking of burned trees along topographic contours in burned areas might be an effective and practical treatment measure for controlling surface soil erosion and reducing stream water turbidity over large areas of burned forest. Damaged trees in burned areas are often cut down to prevent damage from insect epidemics and the felled trees are con- sidered to be waste material (Lim et al., 2010; Ahn et al., in press). Therefore, the construction of CFLEBs from already felled trees would be an effective, economically sound, and ecologically useful measure for controlling surface soil erosion and reducing turbidity in streams.

\section{ACKNOWLEDGEMENTS}

The authors would like to thank Joohoon Lim and Kyung Soo Jang for their assistance with the fieldwork. This research was funded by support from Chonnam National University (2011) in the Republic of Korea. Funding was also supported in part by a Forest Science and Technology Project (S111213L050110) provided by Korea Forest Service in the Republic of Korea.

\section{REFERENCES}

Ahn, Y. S., S. Mizugaki, F. Nakamura and Y. Nakamura 2006 Historical change in lake sedimentation in Lake Takkobu, Kushiro Mire, northern Japan over the last 300 years. Geomorphology, 78: 321-334

Ahn, Y. S., F. Nakamura and S. Mizugaki 2008 Hydrology, suspended sediment dynamics and nutrient loading in Lake Takkobu, a degrading lake ecosystem in Kushiro Mire, northern Japan. Environ. Monit. Assess., 145: 267-281

Ahn, Y. S., F. Nakamura and K. W. Chun 2010 Recent history of sediment dynamics in Lake Toro and applicability of $210 \mathrm{~Pb}$ dating in a highly disturbed catchment in northern Japan. Geomorphology, 114: 284-293

Ahn, Y. S., S. Ryu, C. H. Lee, J. H. Shin, J. H. Lim, B. Lee, W. I. Choi, J. H. Jeong, K. W. An and J. I. Seo 2013 Effects of forest fires on forest ecosystems in eastern coastal areas of Korea and overview of restoration projects. Landscape Ecol. Eng. (in press)

Brose, P. T., D. H. Van Lear and P. D. Keyser 1999 A shelterwoodburn technique for regenerating productive upland oak sites in the Piedmont region. South. J. Appl. For., 23: 158-163

Bruton, M. N. 1985 The effects of suspensoids on fish. Hydrobiologia, 125: 221-241

Choung, Y., B. C. Lee, J. H. Cho, K. S. Lee, I. S. Jang, S. H. Kim, S K. Hong, H. C. Jung and H. L. Choung 2004 Forest responses to the large-scale east coast fires in Korea. Ecol. Res., 19: $43-54$

Chun, K. W. 2003 Characteristics and relevant countermeasures of sediment-related disaster in Korea. In "Prevention Technology of Forest Damage Induced by Post-forest Fire Process", Proceeding of 2003 Forest Restoration Technology Symposium, Chuncheon, Republic of Korea, pp. 1-14 (in Korean)

DeBano, L. F. 2000 The role of fire and soil heating on water repellency in wildland environments: a review. J. Hydrol., 231. 232: 195-206

DeBano, L. F., D. G. Neary and P. F. Ffolliott 2005 Soil physical properties. In "Wildland Fire in Ecosystems: Effect of Fire on Soil and Water", ed. by D. G. Neary, K. C. Ryan and L. F. DeBano, USDA Forest Service Gen Tech Rep RMRS-GTR-42vol 4, Ogden, UT, pp. 29-52

Dedkov, A. P. and V. I. Mozzherin 1996 Erosion and sediment yield on the earth. In "Erosion and Sediment Yield: Global and Regional Perspectives (Proceedings of the Exeter Symposium)", ed. by D. E. Walling and B. W. Webb, IAHS Publ., no. 236, Oxfordshire, pp. 29-33

Hwang, H., S. Ryu and J. Lim 2011 Oak sprout dynamics after 1996 stand-replacing fire in Korea. Forest Sci. Technol., 7: 184-191

Hicks, D. M., J. Hill and U. Shankar 1996 Variation of suspended sediment yields around New Zealand: the relative importance of rainfall and geology. In "Erosion and Sediment Yield: Global and Regional Perspectives (Proceedings of the Exeter 
Symposium)", ed. by D. E. Walling and B. W. Webb, IAHS Publ., no. 236, Oxfordshire, pp. 149-156

Jeong, Y., J. H. Park, K. H. Kim and H. J. Youn 2001 Analysis of the factors influencing the mesopore ratio on the soil surface to investigate the site factors in a forest stand (I): with a special reference to coniferous stands. J. Korean For. Soc., 90: 314-323 (in Korean with English abstract)

Korea Meteorological Administration 2012 Climate data. Available from: http://www.kma.go.kr/

Kutiel, P. and Z. Naveh 1987 The effect of fire on nutrients in a pine forest soil. Plant Soil, 104: 269-274

Larsen, I. J. and L. H. MacDonald 2007 Predicting postfire sediment yields at the hillslope scale: testing RUSLE and disturbed WEPP. Water Resour. Res., 43: W11412

Lemly, A. D. 1982 Modification of benthic insect communities in polluted streams: combined effects of sedimentation and nutrient enrichment. Hydrobiologia, 87: 229-245

Lim, J. 2000 Forest fire and meteorology of eastern Korea. Korean J. Agr. For. Meteorol., 2: 62-67 (in Korean with English abstract)

Lim J., Y. Lee, J. Jeong and M. B. Lee 2010 Post-fire Restoration: To Establish a Healthy and Sustainable Forest Ecosystem. Ukgo publ., Seoul, pp. 6-60

Polyakov, V. O., M. A. Nearing, M. H. Nichols, R. L. Scott, J. J. Stone and M. P. McClaran 2010 Long-term runoff and sediment yields from small semiarid watersheds in southern Arizona. Water Resour. Res., 46: W09512

Robichaud, P. R., J. L. Beyers and D. G. Neary 2005 Watershed rehabilitation. In "Wildland Fire in Ecosystems: Effect of Fire on Soil and Water", ed. by D. G. Neary, K. C. Ryan and L. F. DeBano, USDA Forest Service Gen Tech Rep RMRS-GTR-42vol 4, Ogden, UT, pp. 179-198

Shin, J. H. and D. K. Lee 2004 Strategies for restoration/n of forest ecosystems degraded by forest fire in Kangwon Ecoregion of Korea. Forest Ecol. Manag., 201: 43-56

Shin, J. H., M. B. LEE, J. Lim, Y. G. Lee, K. Koo, Y. H. Kang, M. S. Won, J. H. Sung, J. H. Cho, T. S. Kwon, K. Kim, H. Youn, C. W. Lee, S. H. Lee, K. H. Ka, H. Park, B. S. Park, J. H. Park, S. D. Kim, E. J. Lee, W. S. Lee, E. J. Lee, H. G. Byun, J. E. Lee, G. S Lee, Y. K. Park, S. S. Kim, S. H. Shin, S. W. Han, H. S. Lee and T. H. Kang 2007 Investigation of forest ecosystem change in forest fire damaged areas. Korea Forest Research Institute, Seoul, pp. 19-50 (in Korean)

Spurr, S. H. and B. V. Barnes 1980 Forest Ecology, $3^{\text {rd }}$ ed. John Wiley \& Sons, Inc., New York, pp. 275-294

Yao, S. 2003 Effects of fire disturbance on forest hydrology. J. Forest Res., 14: 331-334 